\title{
Intoxicación etílica y mortalidad por úlcera duodenal en Rusia, 1965-2005.
}

\section{Alcohol poisoning and duodenum ulcer mortality in Russia, 1965 - 2005}

\author{
Yu. E. Razvodovsky \\ Enviar correspondencia a/Correspondence to: \\ Yu. E. Razvodovsky. Grodno State Medical University, Belarus. tel.: + 375015270 18 84, fax: +375 01524353 41, \\ e-mail: razvodovsky@grsmu.by yury_razvodovsky@yahoo.com
}

\section{RESUMEN}

Antecedentes: La úlcera péptica es un problema clínico habitual. Se ha demostrado que el consumo compulsivo de alcohol aumenta el riesgo de úlcera a nivel individual. Objetivo: Calcular el efecto a nivel agregado del consumo compulsivo de alcohol sobre la tasa de mortalidad por úlcera duodenal. Método: Las tendencias de intoxicación etílica fatal por edad y sexo y las tasas de mortalidad por úlcera duodenal en Rusia entre 1965 y 2005 se estudiaron utilizando un análisis ARIMA (promedio autorregresivo integrado de media móvil) para estimar la relación bivariada entre las dos series temporales. Resultados: El análisis de las series temporales indica la presencia de una relación estadísticamente significativa entre las dos series temporales en hombres $(r=0.51$; $S E=0.16)$. La relación entre las dos series temporales también es positiva en el caso de las mujeres, pero no resulta estadísticamente significativa ( $r$ = 0.25; SE = 0.14). Conclusión: Este artículo ofrece nuevas pruebas epidemiológicas de la relación a nivel agregado entre el alcohol y la tasa de mortalidad por úlcera duodenal. El resultado de este estudio apoya asimismo la hipótesis de que el consumo compulsivo de licores de alta gradación constituye un factor de riesgo a nivel individual.

Palabras clave: úlcera duodenal, intoxicación etílica mortal, análisis de series temporales ARIMA, Rusia, 1965-2005.

\section{ABSTRACT}

Background: Peptic ulcer disease is a common clinical problem. Binge drinking has been shown to increase the risk of ulcer at the individual level. Purpose: To estimate the aggregate level effect of binge drinking on duodenum ulcer mortality rate. Method: Trends in age-adjusted, sex-specific fatal alcohol poisoning and duodenum ulcer mortality rates in Russia from 1965 to 2005 were analyzed employing an ARIMA analysis in order to asses a bivariate relationship between the two time series. Results: Time series analysis indicate the presence of statistically significant association between the two series for male ( $r=0.51$; $S E=0.16)$. The association between the two time series for female is also positive, however, statistically not significant ( $r=0.25$; $\mathrm{SE}=$ 0.14). Conclusion: This paper present new epidemiological evidence of aggregate level relationship between alcohol and duodenum ulcer mortality rate. The outcome of this study also supports the hypothesis that binge drinking of strong spirits is a risk factor of ulcer at the individual level.

Key words: duodenum ulcer, fatal alcohol poisoning, ARIMA time series analysis, Russia, 1965-2005.

\section{INTRODUCCIÓN}

$\mathbf{L}$ a úlcera péptica es una de las enfermedades habituales que afectan al sistema digestivo. El riesgo de padecer úlcera a lo largo de la vida es del 5-10\% en los países desarrollados (Sonnenberg \& Everhart, 1996). La patología de la úlcera es compleja y se caracteriza por un exceso de producción

\section{INTRODUCTION}

D eptic ulcer disease is one of the common disorders affecting the digestive system. The lifetime risk of ulcer is $5-10 \%$ in developed countries (Sonnenberg \& Everhart, 1996). The pathology of ulcer is complex and may involve overproduction of acid or pepsin, inadequate mucosal 
de ácido o pepsina, una inadecuada defensa de las mucosas, y reflujo de bilis y jugo pancreático en el estómago (Richardson, 1990). La úlcera péptica es un ejemplo clásico de modelo de enfermedad biopsicosocial y, como la mayoría de las enfermedades, tiene origen multifactorial. Aunque se considera que el Helicobacter pylori provoca la úlcera, hay una variedad de factores huésped, aparte de la infección, que contribuyen de forma importante a esta enfermedad: el tabaco, el consumo de alcohol, la ingestión de antiinflamatorios no esteroideos y el estrés psicosocial (Everhart et al., 1998).

Los estudios sobre la relación entre el consumo de alcohol y el riesgo de úlcera publicados en la última década ofrecen resultados contradictorios. Existen abundantes pruebas clínicas e investigadoras de que el consumo excesivo de alcohol aumenta el riesgo de úlcera de estómago ya que afecta a los mecanismos de defensa de las mucosas (Chow, 1997; Marotta \& Floch, 1991). En un análisis prospectivo Iongitudinal se demostró que, comparados con los que consumían menos de 1,5 unidades de alcohol a la semana, los individuos que consumían $>63$ unidades de alcohol a la semana tenían cuatro veces más posibilidades de padecer úlcera sangrante (Andersen et al., 2000). Por otro lado, varios estudios prospectivos a gran escala han indicado el efecto protector del consumo moderado de alcohol (una o dos unidades diarias) en el desarrollo de la úlcera gástrica (Everhart et al., 1998; Everhart et al., 2000). En el estudio prospectivo de cohorte se observó una tendencia al incremento en la proporción de la incidencia de la úlcera en relación al número de bebidas consumidas dando lugar a una relación en forma de U (Rosenstock et al., 2000). Varios investigadores han observado el efecto protector del consumo de vino y cerveza frente a la infección por Helicobacter pylori activo ( Brenner et al., 1999; Everhart et al., 2000). Son varios los posibles mecanismos biológicos que explican los efectos protectores del consumo moderado de alcohol: 1) La ingesta moderada de alcohol fortalece la defensa de las mucosas por su efecto sobre las prostaglandinas. 2) El incremento de la secreción gástrica y el consiguiente aumento de producción de ácido gástrico refuerzan la actividad antibacteriana. 3) El vino tiene un fuerte efecto antibacteriano (Brenner et al., 1999; Weisse et al., 1995). También está demostrado el efecto específico del vino sobre el riesgo de úlcera: Se ha visto que el vino ejerce un efecto protector contra la ulceración, mientras que la ingesta de licores aumenta el riesgo de padecer úlcera (Rosenstock et al., 2000). Los estudios que han examinado el modelo de consumo de bebidas en relación con el riesgo de úlcera indican que el consumo compulsivo aumenta sustancialmente dicho riesgo. Por ejemplo, el estudio danés demuestra que el consumo de vino se asocia a un riesgo mucho menor que el consumo de cer- defense, reflux of bile and pancreatic juice into stomach (Richardson, 1990). Peptic ulcer is a classical example of the biopsychosocial model of disease and like most diseases, it has a multifactor origin. Although Helicobacter pyloris is considered causal for ulcer a variety of host factors besides infection may play an important contributing role for this disease: smoking, alcohol consumption, non-steroids anti-inflammatory drug use and psychosocial stress (Everhart at al., 1998).

Studies on the relationship between alcohol consumption and risk for ulcer that have been published during the last decade have reported conflicting results. There is large body of clinical and research evidence that excessive alcohol consumption increase the risk of stomach ulcer by impairing of the mucosal defense mechanisms (Chow, 1997; Marotta \& Floch, 1991). In one longitudinal prospective study it was shown that, when compared with those who consumed less than 1.5 units of alcohol per week, individuals who consumed $>63$ units of alcohol per week 4 time more likely to develop bleeding ulcer (Andersen et al., 2000). On the other hand, several large-scale prospective studies have suggested a protective effect of moderate alcohol consumption (one or two drink a day) on the development of gastric ulcer (Everhart at al,. 1998; Everhart at al., 2000). In the prospective cohort study, a tendency towards an increase in the ulcer incidence proportion with the number of consumed drinks was observed resulting in a U-shaped relationship (Rosenstock et al., 2000). Several researchers reported protective effect of wine and beer consumption against the active Helicobacter pylori infection (Brenner et al., 1999; Everhart at al., 2000). There are several possible biological mechanisms that could explain the protective effects of moderate alcohol consumption: 1) moderate alcohol intake might invigorate the mucosal defense by its effects on prostaglandins, 2 ) the increased gastrin secretion and resulting rise in gastric acid production enhance the antibacterial activity, 3) wine has a strong antibacterial effect (Brenner et al., 1999; Weisse et al., 1995). There is also evidence of beverage-specific effect of alcohol on ulcer risk: wine drinking showed a protective effect against ulceration, whereas intake of spirits increased ulcer risk (Rosenstock et al., 2000). Studies that addressed the role of drinking pattern in relation to risk of ulcer suggest that the binge drinking substantially increases the risk. For example, the Danish study provides evidence that wine drinking is associated with a much lower risk than beer drinking (Andersen et al., 2000). This might reflect the fact that beer drinkers are more 
veza (Andersen et al., 2000). Esto puede deberse a que los bebedores de cerveza tienden a beber de forma más compulsiva que los bebedores de vino. Por tanto, la investigación indica que el consumo de alcohol puede influir negativa o positivamente en los factores de riesgo de úlcera, dependiendo de la dosis y del tipo de bebida. En consonancia con estos hallazgos, entendemos que la destructiva combinación de un mayor nivel de consumo de alcohol per cápita y el consumo compulsivo de licores fuertes (sobre todo, vodka) da lugar a una estrecha relación a nivel agregado entre el alcohol y la mortalidad por úlcera en Rusia. Para comprobar esta hipótesis, se analizaron las tendencias de la intoxicación etílica mortal y las tasas de mortalidad por úlcera duodenal entre 1965 y 2005 en Rusia utilizando análisis de series temporales ARIMA.

\section{MATERIAL Y MÉTODOS}

Debe observarse que en Rusia la tasa de intoxicación etílica mortal refleja muy estrechamente el nivel de consumo de alcohol. Es más, la tasa de intoxicación etílica como indicativo de consumo compulsivo de alcohol capta mejor la magnitud del hábito de beber orientado a la embriaguez que las estadísticas oficiales de ventas y el cálculo de los expertos sobre el nivel total de consumo de alcohol. Esto resulta muy evidente si tenemos en cuenta que el cálculo fiable del consumo total de alcohol a nivel de la población en las antiguas repúblicas soviéticas es muy difícil. Un método habitual consiste en utilizar la tasa de intoxicación etílica mortal como indicativo de consumo compulsivo de alcohol en estos países (Pridemore, 2002).

Los datos sobre tasas de mortalidad por úlcera duodenal e intoxicación etílica moral en función de la edad y el sexo por cada cien mil habitantes se obtuvieron del sistema de registro de estadística vital de Rusia. El análisis estadístico se realizó con el paquete "Estadística 6». Se da por descontado que las correlaciones bivariadas entre dos series temporales sin refinar son espurias debido a las fuentes comunes de tendencias y a la autocorrelación (Norstrom \& Skog, 2001). Para reducir el riesgo de obtener una relación espuria entre dos variables con tendencias comunes, las tendencias deben eliminarse por medio de un procedimiento de diferenciación: $\nabla x_{t}=x_{t}-x_{t-1}$ Lo cual implica analizar los cambios anuales en vez de los datos sin refinar. El proceso de eliminar la variación sistemática en las series temporales antes de examinar la relación de causas potenciales se denomina "preblanqueamiento». Los residuos de una serie temporal estadísticamente adaptada se distribuyen como un proceso de ruido blanco. Posteriormente, se likely to take alcohol in binge session than wine drinkers. Thus, research evidence suggests that alcohol consumption may be related to positive or negative risk factors of ulcer, depending on the dose and type of drinking. In line with these findings, we assume that the devastating combination of the higher level of alcohol consumption per capita and binge drinking strong spirits (predominantly vodka) would result in close aggregate-level association between alcohol and ulcer mortality in Russia. To test this hypothesis, trends in fatal alcohol poisoning and duodenum ulcer and mortality rates from 1965 to 2005 in Russia were analyzed employing ARIMA time series analysis.

\section{MATERIAL AND METHODS}

It should be noted, that in Russia the fatal alcohol poisoning rate closely reflects the level of alcohol consumption. Moreover, the alcohol poisoning rate as indicator of binge drinking may better capture the magnitude of the intoxication-oriented drinking pattern than official sales statistics and an expert estimation of the total level of alcohol consumption. This is especially true if we keep in mind that reliable estimation of total alcohol consumption at the population level in the former Soviet republics is a tremendously difficult task. Thus, a common approach is to use the fatal alcohol poisoning rate as an indicator of binge drinking in these countries (Pridemore, 2002).

The data on age-adjusted sex-specific duodenum ulcer and alcohol poisoning mortality rates per 1000.000 of residents were taken from the Russian vital statistics registration system. The statistical analysis was conducted with the package "Statistica 6". It is generally agreed that bivariate correlations between two raw time-series are spurious due to common sources of trends and autocorrelation (Norstrom \& Skog, 2001). Therefore in order to reduce the risk of obtaining a spurious relation between two variables that have common trends, the trends should be removedby means of a differencing procedure: $\nabla x_{t}=x_{t}-x_{t-1}$ This means analyzing annual changes rather than raw data. The process of removing systematic variation within time series prior to the examination of potential causal relationships is referred to as "prewhitening". The residuals of a statistically adequate time series are distributed as a white noise process. A further step entails the inspection of the cross correlation function 
procede a la observación de la función de correlación cruzada para calcular la asociación entre las dos series temporales preblanqueadas. El último paso consiste en cierto número de controles diagnósticos (cálculo de una estadística del test de Box-Jenkins en caso de hipótesis nula para demostrar que los residuos del modelo se distribuyen como ruido blanco, y una estadística del Q-test de Box-Ljung en caso de hipótesis nula para demostrar que la serie de valores de las correlaciones cruzadas es independiente en su conjunto). Esta técnica de análisis de series temporales fue formulada por Box y Jenkins y se conoce como modelo ARIMA (promedio autorregresivo integrado de media móvil) (Box \& Jenkins, 1976). En este artículo utilizamos dicho modelo para calcular la relación entre las series temporales de tasas de intoxicación etílica mortal (como indicador de consumo compulsivo de alcohol) y tasas de mortalidad por úlcera de estómago. Se espera que el cambio en el consumo de alcohol a nivel agregado tenga efecto inmediato en los problemas agudos relacionados con el alcohol (como accidentes y lesiones), y a largo plazo en los problemas crónicos (cirrosis hepática). Puesto que la úlcera duodenal se incluye más en los problemas crónicos que en los agudos, tendremos que esperar varios años para ver la respuesta de la mortalidad a los cambios en el consumo de alcohol a nivel agregado. Por tanto, hemos de tener en cuenta la cuestión del intervalo temporal. Para solventar este problema analizamos las correlaciones cruzadas entre las dos series temporales en diferentes intervalos.

\section{RESULTADOS}

Según las estadísticas oficiales, la tasa de mortalidad por úlcera duodenal se multiplicó por 2.4 en hombres (de 17.7 a 41.7 por cada cien mil residentes) y por 4.7 en mujeres (de 2.6 a 12.3 por cada cien mil residentes) en Rusia entre 1965y 2005. La tasa de intoxicación etílica mortal en hombres se multiplicó por 2.9 (de 59.7 a 468.7 por cada millón de habitantes) y por 4.1 en mujeres (de 27.9 a 113.6 por cada millón de habitantes). Las tendencias de las tasas de úlcera duodenal y mortalidad por intoxicación etílica por edades y sexos se ofrecen en los cuadros 1 y 2. Como se puede observar, hay una tendencia ascendente general en las dos series temporales tanto para hombres como para mujeres. La evidencia gráfica indica también una estrecha relación entre las tendencias de úlcera duodenal y mortalidad por intoxicación etílica en hombres. Estas tendencias se correlacionan con las grandes transformaciones sociales. El descenso sustancial en las dos series temporales a mediados de los años ochenta, se corresponde con la campaña antialcohólica de 1985-1988, que redujo significativa- in order to estimate the association between the two prewhitened time series. The final step involves a number of diagnostic checks (calculating a BoxJenkins test statistic for the null hypothesis in order to show that the model residuals are distributed as white noise, and a Box-Ljung Q-test statistic for the null hypothesis to demonstrate that the set of values for the cross correlations is jointly independent). This technique for undertaking time series analysis has been suggested by Box and Jenkins and is often referred to as ARIMA (autoregressive integrated moving average) model (Box a \& Jenkins, 1976). We used this model to estimate the relationship between the time series of fatal alcohol poisoning rate (as a proxy for binge drinking) and stomach ulcer mortality rate in this paper. A change in aggregate level drinking is expected to have an immediate effect on acute forms of alcohol-related problems (such as accidents and injuries), as well as a longterm effect on chronic problems (liver cirrhosis). As duodenum ulcer attributed to the chronic rather than acute alcohol-related problems we should expect that the mortality response to changes in aggregate level alcohol consumption will be distributed over several years. Thus, we should consider the timelag problem. In order to deal with this problem we inspected the cross-correlations between the two time series at different lags.

\section{RESULTS}

According to official statistics, the duodenum ulcer mortality rate increased 2,4 times (from 17.7 to 41.7 per 1000.000 of residents) for male and 4.7 times (from 2.6 to 12.3 per 1000.000 of residents) for female in Russia from 1965 to 2005. The fatal alcohol poisoning rate for male increased 2.9 times (from 159.7 to 468.7 per 1000.000 of population), and for female increased 4.1 times (from 27.9 to 113.6 per 1000.000 of population). The trends in age-adjusted, sex-specific duodenum ulcer and alcohol poisoning mortality rates are displayed in Figures 1-2. As can be seen, there is general upward trend in the two time series both for male and female. The graphical evidence also suggests quite a strong association between the trends in duodenum ulcer and alcohol poisoning mortality for men. These trends have been more or less correlated with the great societal transformation. The substantial decreases in the two time series in the mid-1980s corresponds with the anti-alcohol campaign of 1985-1988, witch significantly reduced 


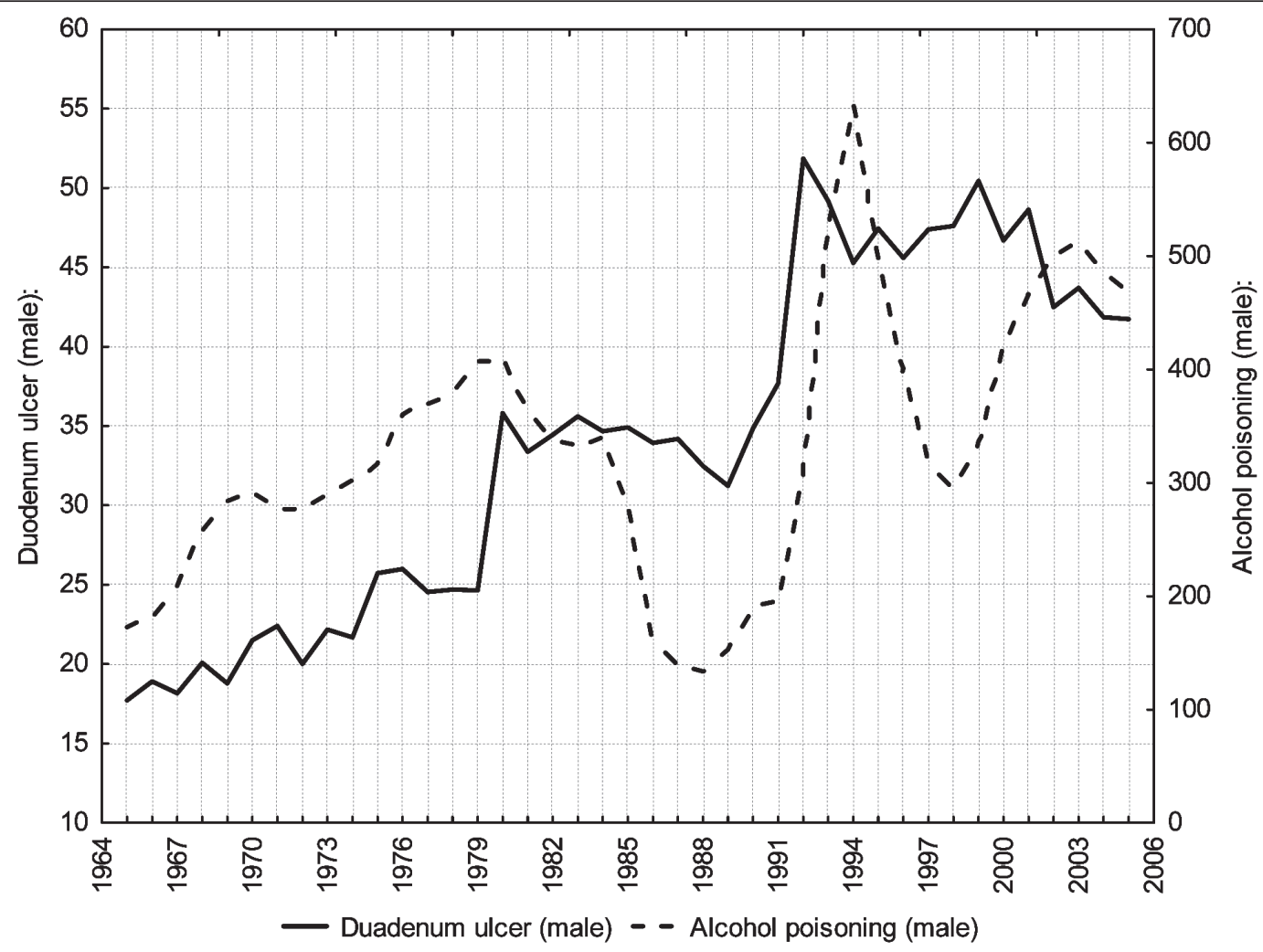

Cuadro 1.- Dinámica de la tasa de mortalidad por úlcera duodenal y por intoxicación etílica en hombres en Rusia entre 1965 y 2005. Figure 1.- Dynamics of duodenum ulcer and alcohol poisoning mortality rate for male in Russia from 1965 to 2005.

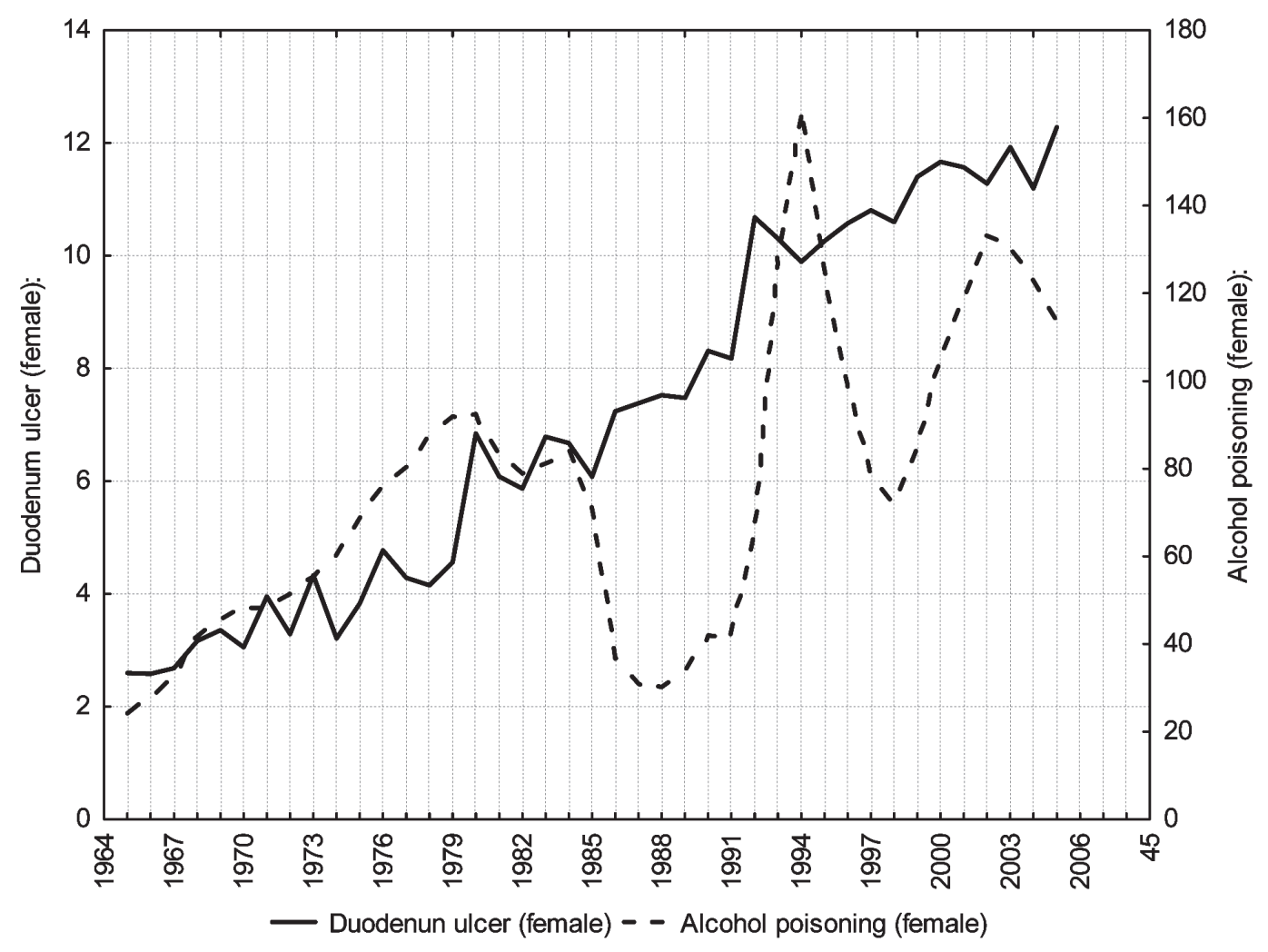

Cuadro 2.- Dinámica de la tasa de mortalidad por úlcera estómago y por intoxicación etílica en mujeres en Rusia entre 1965 y 2005. Figure 2.- Dynamics of stomach ulcer and alcohol poisoning mortality rate for female in Russia from 1965 to 2005. 
mente el consumo de alcohol limitando su fabricación y circulación, y los notables incrementos de principios de los noventa se corresponden con los profundos cambios socioeconómicos y políticos del período de transición. Es importante señalar que las tendencias de intoxicación etílica mortal son muy similares en hombres y en mujeres; sin embargo, hay una marcada discrepancia en función del sexo en las tendencias de mortalidad por úlcera duodenal. El descenso de la tasa de mortalidad por úlcera a mediados de los ochenta y el subsiguiente aumento a principios de los noventa fueron mucho mayores en hombres que en mujeres. Por ejemplo, la tasa de mortalidad por úlcera en hombres aumentó el 66\% entre 1989 y 1992, y la tasa de mortalidad en mujeres aumentó el 35\%.

El análisis de correlación de Pearson muestra una estrecha relación entre las dos variables en hombres ( $r$ $=0.52 ; p<0,000)$ y en mujeres $(r=0.73 ; p<0,000)$. Como se observa en los cuadros 1 y 2, hay una tendencia lineal en las cuatro series temporales. Esta tendencia se eliminó a través de una diferenciación de primer orden. La fórmula general de modelo ARIMA univariado en la serie temporal de mortalidad masculina por úlcera duodenal es $(p=1, q=1, d=1)$ y en la serie temporal de intoxicación etílica mortal es ( $p$ $=1, q=0, d=1)$. La fórmula general del modelo univariado en las series temporales de intoxicación etílica mortal y mortalidad por úlcera duodenal en mujeres es ( $p=1, q=0, d=1)$, donde $p$ es el orden del proceso autorregresivo, q el orden del proceso de media móvil y d el gado de diferenciación. Estos modelos cumplen el criterio diagnóstico de estacionaridad; por ejemplo, donde los residuos se distribuyen como proceso de ruido blanco y ninguna de las funciones de autocorrelación resulta significativa a nivel 0.005. Como hemos eliminado la correlación espuria, podemos calcular la función de correlación cruzada en intervalos diferentes con el fin de identificar las relaciones bivariadas. La función de correlación cruzada indica la presencia de una asociación estadísticamente significativa entre las dos series temporales en el caso de los hombres a 1 DAM (desviación absoluta mínima) ( $r=0.37$, SE $=0.16$ ). La relación entre las dos series temporales preblanqueadas también es positiva en el caso de las mujeres, aunque no resulta estadísticamente significativa $(r=0.24 ;$ SE $=0.14)$.

\section{DEBATE}

El análisis de las series temporales indica una relación positiva entre la intoxicación etílica mortal (como indicador del consumo compulsivo de alcohol) y mortalidad masculina por úlcera duodenal a intervalo 1. Por tanto, existe fundamento para creer que, en este caso, la variable independiente influye en la alcohol consumption by limiting its manufacture and availability, and the dramatic increases in the early 1990s corresponds with the profound socioeconomic and political changes occurring during the transitional period. It is important to point out that the trends of fatal alcohol poisoning for men and women are very similar, while there are marked discrepancy between sex-specific duodenum ulcer mortality trends. The decrease in ulcer mortality rate in the mid-1980s and the subsequent increases in the early 1990s were substantially greater for men than for women. For example, male ulcer mortality rate increased by $66 \%$ from 1989 to 1992, and female mortality rate increased by $35 \%$.

A Pearson correlation analysis suggests a strong association between the two variables for male $(r=0.52 ; p<0,000)$ and for female $(r=0.73 ; p<$ $0,000)$. As can be seen from Figures 1-2, there is a linear trend in the four time series. This trend was removed by means of first-order differencing. The general form of the univariate ARIMA model for male ulcer mortality time series is $(p=1, q=1, d=$ 1 ), and for fatal alcohol poisoning time series is ( $p=$ $1, q=0, d=1)$. The general form of the univariate model for female fatal alcohol poisoning and ulcer mortality time series is $(p=1, q=0, d=1)$, where $p$ - is the order of the autoregressive process, $q$ - the order of the moving average process, $d$ - the degree of differencing,. These models met the diagnostic criterion of stationarity i.e. where the residuals are distributed as a white noise process and none of the autocorrelation functions are significant at the 0.005 level. As we have removed the spurious correlation, we can estimate the cross correlation function at different lags in order to identify the bivariate relationships. The cross correlation function indicates the presence of statistically significant association between the two time series for male at $1 \mathrm{lad}(r=0.37$; SE $=0.16$ ). The association between the two prewhitened time series for female also positive, however, statistically not significant $(r=$ 0.24 ; SE $=0.14)$.

\section{DISCUSSION}

Time series analysis suggests a positive relationship between fatal alcohol poisoning (as a proxy for binge drinking) and male duodenum ulcer mortality at 1 lag. Therefore, we have a reason to believe that, in this case, independent variable is influencing the dependent one, and there is evidence 
dependiente y hay pruebas de una relación rezagada entre las dos series temporales. Conviene observar que el tamaño de la relación bivariada entre intoxicación etílica y úlcera en hombres es mucho mayor que en mujeres. Este hecho especialmente relevante a la luz de las pruebas empíricas indica que en Rusia el consumo compulsivo de alcohol está profundamente arraigado en la cultura masculina (Nemtsov, 2003).

En este punto debemos señalar una serie de limitaciones del estudio que afectan al resultado. Cabe la posibilidad de que un elemento de confusión influya en las dos variables; a saber, una correlación espuria. Varios investigadores han afirmado que el malestar psicosocial derivado de los radicales cambios políticos, económicos y sociales, fue el principal determinante del gran incremento del consumo de alcohol y jugó un papel esencial en la crisis de la mortalidad rusa a principios de los años noventa (Gavrilova et al., 2000). Está demostrada la relación entre el estrés y la úlcera (Levenstein et al., 1999). Hay pruebas de que el estrés psicosocial constituye no de los principales factores de riesgo de úlcera, mientras que el Helicobacter no sirve como explicación monocausal ya que la mayoría de los afectados no desarrollan úlcera (Levenstein, 1998). En un estudio longitudinal se demostró que, tras corregir los potenciales elementos de confusión (edad, sexo, educación, tabaquismo y consumo habitual de aspirinas), las personas que se declaraban estresadas tenían 1.8 más probabilidades de padecer úlcera que las restantes (Anda et al., 1992). Esto indica que las personas que consideran que sus vidas son estresantes sufren mayor riesgo de padecer úlcera. En otro estudio, la frecuencia de úlcera en un período de nueve años era mayor en sujetos que declaraban de partida factores estresantes vitales e inestabilidad psicológica (Levenstein et al., 1997). Los datos del examen clínico también indican que la úlcera afecta más a individuos con trastornos de ansiedad y depresivos (Goodvin \& Murray, 2002). El malestar psicosocial constituye así un importante factor subyacente en el gran incremento de la intoxicación etílica mortal y de la tasa de mortalidad por úlcera a finales de los ochenta y principios de los noventa. A este respecto, es importante subrayar que la dinámica de la mortalidad masculina por úlcera en los años ochenta y noventa encaja con el típico modelo relacionado con el estrés: gran incremento a principios de los noventa (período agudo) y descenso a finales de los noventa (período de adaptación). Por otro lado, la marcada discrepancia entre las dos series temporales en hombres: tendencia ascendente de intoxicación etílica mortal y tendencia descendente de la tasa de mortalidad por úlcera entre 1998 y 2003, apoya la hipótesis de la relación con el estrés. Sin embargo, entendemos que el malestar psicosocial no explica totalmente el significativo of lagged relationship between the two time series. It is important to point out that the size of the bivariate association between alcohol poisoning and ulcer for men is substantially greater than for women. This fact especially relevant in light of empirical evidence that suggests that in Russia binge drinking is deeply rooted part of the male culture (Nemtsov, 2003).

At this stage we should to point out several limitations of the study that may have affected the outcome. One can assume that the two variables are being influenced by a confounder variable i.e. spurious correlation. Several scholars have argued that the psychosocial distress resulting from the dramatic social, economic and political changes, was the main determinant of the sharp increase of alcohol consumption and appear to have played a central role in the Russian mortality crisis in early 1990s (Gavrilova et al., 2000). The relationship between stress and ulcer has been well established (Levenstein et al., 1999). There is evidence that psychosocial stress is a major risk factor for ulcer, while Helicobacter is inadequate as a monocausal explanation since most infected people do not develop ulcer (Levenstein, 1998). In one longitudinal study it was shown that after adjustment for potential confounders (age, sex, education, smoking, and regular aspirin use) persons who perceived themselves as stressed were 1.8 times more likely to develop ulcers than those who did not (Anda et al., 1992). This finding also suggests that persons who perceive their lives as stressful may be at increased risk for the development of ulcer. In another study, the occurrence of self reported ulcer over a nine year period was more likely in subjects who reported life stressors or psychological distress at baseline (Levenstein et al., 1997). Dates from clinical sample have also suggested that ulcer occurs more frequently among individuals with anxiety and depressive disorders (Goodvin \& Murray, 2002). So, psychosocial distress may be an important underlying factor for the dramatic increase of fatal alcohol poisoning and ulcer mortality rate in late 1980s - early 1990s. In this respect, it is important to note that dynamics of male ulcer mortality in 1980s - 1990s fits the typical stress-related pattern: dramatic growth in the early 1990-s (acute stage) and decrease in late 1990s (stage of adaptation). Moreover, marked discrepancy between the two time series for male: upward trend of fatal alcohol poisoning and downward trend of ulcer mortality rate in 1998-2003 support stress-related hypotheses. However, it seems plausible that psychosocial distress not a sufficient explanatory factor for the significant decrease in alcohol poisoning and ulcer mortality rate in mid-1980s. Thus, rather than playing 
descenso de las tasas de intoxicación etílica y mortalidad por úlcera a mediados de los ochenta. Y así, más que actuar como principal factor causal, el malestar psicosocial representa un factor de confusión.

Los resultados de las investigaciones indican que parte de los efectos adversos del alcohol se pueden atribuir al alcohol asociado con conductas como el tabaquismo (Chow, 1997). Fumar más de quince cigarrillos al día multiplica por tres el riesgo de úlcera perforada en comparación con quienes no fuman (Andersen et al., 2000). El consumo simultáneo de alcohol y tabaco, dependiendo de las dosis, potencia los daños de la mucosa gástrica provocados por el etanol (Ko \& Cho, 2000). La reducción de la secreción de mucus, el incremento en la concentración de leucotrieno B1, la actividad de la mieloperoxidasa y de la síntesis inducida del óxido nítrico acompañaron a dichos efectos potenciadores (Chou, 1994). Las conclusiones afirman asimismo que el tratamiento crónico con nicotina intensifica la ulceración gástrica provocada por el estrés (Wong et al., 2002). La gran preponderancia del tabaquismo entre los hombres rusos explica en parte la elevada tasa de mortalidad masculina por úlcera en comparación con la femenina. Sin embargo, hay escasas pruebas de cambios rápidos en los hábitos fumadores de los rusos a principios de los noventa que hayan dado lugar a un crecimiento desmesurado de la tasa de mortalidad por úlcera. A este respecto sería interesante examinar el impacto de posibles elementos de confusión en la relación entre úlcera y alcohol en posteriores análisis. Por tanto, son necesarias más investigaciones para cuantificar la contribución del consumo compulsivo de alcohol, el malestar psicosocial y el tabaquismo a la tasa de mortalidad por úlcera duodenal.

En conclusión, los resultados del presente estudio indican una relación positiva entre alcohol y tasa de mortalidad masculina por úlcera duodenal a nivel agregado y apoyan la hipótesis de que el consumo compulsivo de bebidas de fuerte gradación alcohólica constituye un factor de riesgo de úlcera duodenal a nivel individual. El resultado de este estudio apoya asimismo la hipótesis de que el alcohol jugó un papel esencial en la crisis de mortalidad registrada en Rusia a principios de los años noventa.

\section{AGRADECIMIENTOS.}

El autor desea agradecer al profesor A. V. Nemstov su apoyo y valiosos consejos. the major causal role, psychosocial distress may represent a confounding factor.

The research evidence also suggests that some of the adverse effects of alcohol may be attributed to alcohol associated behavior such a smoking (Chow, 1997). Smoking more than 15 cigarettes per day raised the risk of perforated ulcer more than threefold as compared with lifetime abstinence from smoking (Andersen et al., 2000). Concurrent consumption of alcohol and cigarette smoking dosedependently potentiated ethanol-induced gastric mucosal damage (Ko \& Cho, 2000). The reduction of mucus secretion, increase in leukotriene B1 concentration, myeloperoxidase and inducible nitric oxide synthase activities accompanied such potentiating effect (Chou, 1994). The findings also suggest that chronic nicotine treatment intensifies stress-evoked gastric ulceration (Wong et al., 2002). The high prevalence of smoking among Russian men probably explains a part of the high male ulcer mortality rate compared with female mortality rate. However, there is little evidence of rapid changes in smoking pattern among Russian men in the early 1990s that have translated into dramatic grows of ulcer mortality rate. In this respect it would be interesting to examine the impact of potential confounders on ulcer-alcohol relationship in further analysis. Therefore further research is necessary to quantify the contribution of binge drinking, psychosocial distress and smoking to the duodenum ulcer mortality rate.

In conclusion, the results of present study suggest a positive association between alcohol and male duodenum ulcer mortality rate at aggregate level and support the hypothesis that binge drinking of strong spirits is a risk factor of duodenum ulcer at the individual level. The outcome of this study also supports the hypothesis that alcohol has played a crucial role in the Russian mortality crisis in the early 1990s.

\section{ACKNOWLEDGEMENTS}

The author would like to thank Professor A.V. Nemtsov for his support and valuable advice. 


\section{REFERENCIAS/ REFERENCES}

1. Anda, R.F., Williamson, D.F., Escobedo, L.G. (1992): Self-perceived stress and the risk of peptic ulcer disease. A longitudinal study of US adults. Arch Intern Med, 152:829-33.

2. Andersen, I.B., Jørgensen, T., Bonnevie, O., et al. (2000): Smoking and alcohol intake as risk factors for bleeding and perforated peptic ulcers: a populationbased cohort study. Epidemiology, 11:434-9.

3. Box, G.E.P., Jenkins, G.M. Time Series Analysis: forecasting and control. London. Holden-Day Inc. 1976

4. Brenner, H., Rothenbacher, D., Bode, G., et al. (199): Inverse graded relation between alcohol consumption and active infection with Helicobacter pylori. Am J Epidemiol, 149:571-6.

5. Chou, S.P. (1994): An examination of the alcohol consumption and peptic ulcer association-Results of a national survey. Alcohol Clin Exp Res, 18:149-53.

6. Chow, J., Ma, L., Zhu, M., Cho, C.H. (1997): The potentiating actions of cigarette smoking on ethanol-induced gastric mucosal damage in rats. Gastroenterology, 113(4):1188-97.

7. Everhart, J.E., Byrd-Holt, D., Sonnenberg, A. (1998): Incidence and risk factors for self-reported peptic ulcer disease in the United States. Am J Epidemio,I 147:529-36.

8. Everhart, J.E., Kruszon-Moran, D., Perez-Peres, G.I., et al., (2000): Seroprevalence and ethnic differences in Helicobacter pylori infection among adults in the Unites States. J Infect Dis, 181:1359-63.

9. Gavrilova, N.S., Semyonova, V.G., Evdokushkina, G.N., Gavrilov, L.A. The response of violent mortality to economic crisis in Russia. Population Research and Policy Review, 19:397-419.

10. Goodvin, R.D., Murray, B.S. (2002): Generalized anxiety disorder and peptic ulcer disease among adults in the US. Psychosomatic Medicine, 64:862-866.

11. Ko, J.K., Cho, C.H. (2000): Alcohol drinking and cigarette smoking: a "partner" for gastric ulceration. Zhonghua Yi Xue Za Zhi, 63(12):845-54.
12. Levenstein, S. (1998): Stress and peptic ulcer: life beyond helicobacter. BMJ, 316:538-41.

13. Levenstein, S., Ackerman, S., Kiecolt-Glaser, J.K., et al., (1999): Stress and peptic ulcer disease. JAMA, 281:10-11.

14. Levenstein, S., Kaplan, G.A., Smith, M.W. (1997): Psychological predictors of peptic ulcer incidence in the Alameda County study. J Clin Gastroenterol, 24:140-6.

15. Marotta, R.B., Floch, M.H. (1991): Diet and nutrition in ulcer disease. Med Clin North Am ,74:967-79.

16. Nemtsov, A. (2003): Suicide and alcohol consumption in Russia, 1965-1999. Drug and Alcohol Dependence, 71:161-168.

17. Norstrom, T., Skog, O.J. (2001): Alcohol and mortality: methodological and analytical issue in aggregate analysis. Addiction, 96: 5-17.

18. Pridemore, W.A. (2002): Vodka and violence: alcohol consumption and homicide rates in Russia. American Journal of Public Health, 92 (12): 1921-1930.

19. Richardson, C.T. (1990): Role of aggressive factors in the pathogenesis of peptic ulcer disease. Scand $J$ Gastroenterol, 174(suppl):37-43.

20. Rosenstock, S.J., Jørgensen, T., Andersen, L.P., et al., (2000): Association of Helicobacter pylori infection with lifestyle, chronic disease, body-indices, and age at menarche in Danish adults. Scand J Public Health, 28:32-40.

21. Sonnenberg, A., Everhart, J.E. (196): Prevalence of self-reported peptic ulcer in the United States. Am J Public Health, 86:200-205.

22. Weisse, M.E, Eberly, B., Person, D.A. (1995): Wine as a digestive acid: comparative antimicrobial effects of bismuth salicylate and red and white wine. BMJ, 311:1657-60.

23. Wong, D., Koo, M.W., Shin, V.Y. at al., (2002): Pathogenesis of nicotine treatment and its withdrawal on stress-induced gastric ulceration in rats. Eur $\mathrm{J}$ Pharmacol, 34(1-2):81-86. 
